\title{
Microbiological investigation and determination of the antimicrobial potential of cow dung samples
}

\author{
Saurab Kishore Munshi ${ }^{1}$, Juel Roy ${ }^{1}$ and Rashed Noor ${ }^{2} *$ \\ ${ }^{1}$ Department of Microbiology, Stamford University Bangladesh, 51 Siddeswari Road, Dhaka 1217, Bangladesh \\ ${ }^{2}$ School of Life Sciences (SLS), Independent University, Bangladesh (IUB), Plot 16, Block B, Aftabuddin Ahmed \\ Road, Bashundhara, Dhaka 1229, Bangladesh
}

Received 03 September 2018/Accepted 02 October 2018

\begin{abstract}
Cow dung is being used in agriculture as well for the household and religious purposes from the ancient time. Cow dung is known to possess antimicrobial activity and contains a wide variety of microorganisms with variable properties. Therefore, the present study was carried out to assess the microbial diversity including pathogenic ones of the cow dung samples as well as to determine the antimicrobial traits of the samples. In this regard, a total of 8 fresh cow dung samples were tested. All the samples contained a huge load of bacteria and fungi in an average of $10^{8}$ and $10^{7} \mathrm{cfu} / \mathrm{g}$, respectively. An extended number of pathogenic bacteria were recovered. Among the pathogenic bacteria, Staphylococcus spp. and Bacillus spp. were predominantly found in every sample. The presence of Pseudomonas spp. Escherichia coli, Klebsiella spp. and fecal coliform were exhibited in most of the samples. Salmonella spp. and Vibrio spp. were found in 3 and 5 samples, respectively. The average load of the pathogens was $10^{4} \mathrm{cfu} / \mathrm{g}$. All the samples showed substantial degree of antimicrobial activity against all the pathogens tested. Samples $1,2,3$ and 4 were effective in inhibiting the growth of all the tested pathogens. The findings of the present study revealed the need for safe application of cow dung in the agricultural field and of further investigation for the antimicrobial potential of the diversified microflora of cow dung offering agricultural, environmental and medical applications.
\end{abstract}

Key words: Cow dung; Microbiological analysis; Antibacterial activity

Cow dung is the excreted undigested residue of consumed food material of herbivorous bovine animal species mixed of feces and urine in the ratio of 3:1 and mainly consists of lignin, cellulose and hemicelluloses (1). A total of 24 different minerals such as nitrogen, potassium, along with trace amount of sulfur, iron, magnesium, copper, cobalt and manganese are found in cow dung $(2,3)$. It is traditionally used as organic fertilizer for centuries in the Indian subcontinent. The addition of cow dung raises the mineral status of soil, enhances plant resistance against pests and diseases; accelerate plant growth and other beneficial activities such as sulfur oxidation and phosphorous solubilization (3).

Lower part of the gut of the cow is known to harbor various microorganisms including Lactobacillus plantarum, Lactobacillus casei, Lactobacillus acidophilus, B. subtilis, Enterococcus diacetylactis, Bifidobacterium and yeasts (commonly Saccharomyces cerevisiae) mostly have probiotic activity (3, 4). Apparently, cow dung consists mostly of the above mentioned micro flora $(3,4)$. Normally aged cow dung may be contaminated with several soil inhabitant microorganisms such as bacteria, fungi, Trichoderma

*Corresponding Author: Mailing address. Dr. Rashed Noor, Associate Professor, School of Life Sciences (SLS), Independent University, Bangladesh (IUB), Plot 16, Block B, Aftabuddin Ahmed Road, Bashundhara, Dhaka 1229, Bangladesh; E-mail: rashednoor@iub.edu.bd. and Actinomycetes. Pathogens may get access to cow dung and it becomes a potential medium for the dissemination of a significant number of pathogens in the agricultural lands (5). Application of untreated may responsible for the contamination of soil, irrigation water, crops, vegetables and the plants with human pathogenic bacteria such as Salmonella spp., Listeria monocytogenes, Escherichia coli 0157:H7 and other verotoxin-producing bacteria (6).

Cow dung has long been used for cooking purpose by direct burning in rural areas of Bangladesh. It has its application in plastering of walls and floor in villages for providing insulation during winter and summer. It can also be used as mosquito repellent through smoke generated from the burnt cow dung and subsequently ashes are applied for cleaning kitchen utensils from ancient time (7). Cow dung can act as a raw material in biogas generation as well as coproduct in agriculture, such as manure, biofertiliser, biopesticides, pestrepellent and as a source of energy (7). It is also considered to be a purifier for all the wastes in the nature (3). Detailed study of cow dung is gaining interest for utilizing its potential in the field of energy production and pharmaceutical products around the world at present.

Several studies evident the antifungal and antiseptic activities of fresh cow dung and cow urine $(8,9)$. Secretion of antimicrobial metabolites by cow dung microflora might play a major role for these properties $(8$, 
9). Therefore, the present study was undertaken to isolate and characterize the cow dung microflora and its pathogenic inhabitants along with the determination of the effectiveness of cow dung as a potential cleaning agent or antiseptic through assay for antimicrobial activity.

\section{MATERIALS AND METHODS}

Study area, sampling and sample processing. Eight different types of fresh cow dung samples of Bangladeshi cow breed were randomly collected from different cow farm located at khillgaon, Savar, Gabtoli and Rampura of Dhaka city, Bangladesh following standard protocol $(10,11)$ For the identification and enumeration of bacteria including pathogenic ones and fungi, $10 \mathrm{~g}$ of each sample was added with $90 \mathrm{ml}$ of normal saline and diluted up to $10^{-7}$ for all the samples following standard guidelines (11-14).

Isolation and identification of bacteria

Estimation of total viable bacteria, Escherichia coli, Klebsiella spp., Staphylococcus spp. Bacillus spp. and Pseudomonas spp. For each of the cases, $0.1 \mathrm{ml}$ of samples from the dilution $10^{-5}$ and $10^{-7}$ was introduced on to the nutrient agar and sabouraud dextrose agar for the isolation of total viable bacteria and fungi, respectively. Likewise, $0.1 \mathrm{ml}$ of each sample from the dilution $10^{-3}$ and $10^{-5}$ was introduced onto MacConkey agar, mannitol salt agar (MSA), starch agar and Pseudomonas agar for the isolation of coliforms (Escherichia coli and Klebsiella spp.), Staphylococcus spp., Bacillus spp. and Pseudomonas spp., consecutively. All the plates were then incubated at $37{ }^{\circ} \mathrm{C}$ for 24 hours (11-15).

Isolation of Salmonella spp., Shigella spp. and Vibrio spp. after enrichment. By considering the possible occurrence of viable but nonculturable (VBNC) cells $(14,16-18) 10 \mathrm{ml}$ of sample was transferred into 90 $\mathrm{ml}$ of and alkaline peptone water (APW) for the enrichment of Salmonella, Shigella, and Vibrio spp., respectively and incubated at $37^{\circ} \mathrm{C}$ for 6 hours. After incubation, the samples were diluted up to $10^{5}$ and then $0.1 \mathrm{ml}$ of samples from each of the dilutions were spread onto Salmonella-Shigella (SS) agar and thiosulfate citrate bile salt sucrose (TCBS) agar for the isolation of Salmonella spp. \& Shigella spp., and Vibrio spp., consecutively. Plates were incubated at 37 ${ }^{\circ} \mathrm{C}$ for 48 hours for the detection of typical colonies.

Biochemical identification of the bacterial isolates. Finally, all the isolates were biochemically examined for their identification following standard procedures as described earlier $(11,13,14,19)$.

Assay for the In vitro antimicrobial activity of the cow dung samples. For the determination of antimicrobial activity, modified agar well diffusion method was followed using Mueller-Hinton agar plate $(10,14,20,21)$. Suspensions of different bacteria such as E. coli, Pseudomonas spp., Bacillus spp., Vibrio spp., Klebsiella spp. and Salmonella spp. introduced on to the MHA agar were prepared using normal saline, consisting of $10^{5} \mathrm{cfu} / \mathrm{ml}$ with a turbidity equivalent to that of the $0.5 \mathrm{ml} \mathrm{McFarland} \mathrm{standard,} \mathrm{and} \mathrm{each} \mathrm{suspension} \mathrm{was}$ then subjected to lawn on the Muller-Hinton agar (MHA). The wells were dug $\left(8 \mathrm{~mm}^{3}\right)$ on the inoculated Muller Hinton agar medium and $100 \mu \mathrm{l}$ or $11 \mathrm{mg} / \mathrm{ml}$ of each sample were introduced. Normal saline was used as negative controls whereas antibiotic disk of Gentamycin (GEN, $10 \mu \mathrm{g}$ ) was used as positive control. The plates were incubated at $37^{\circ} \mathrm{C}$ overnight and examined for the zone of inhibition. The diameter of the inhibition zone was measured in $\mathrm{mm}$ using slide calipers.

\section{RESULTS AND DISCUSSION}

Determination of the presence of microorganisms in fresh cow dung samples. The present study was attempted to assess the microbial diversity of the fresh cow dung samples by culture based method as diverse microorganisms have been reported to be present in cow dung, which include bacteria and fungi in previous studies $(1,22,23)$. Cow dung can be considered as an potential source of microbial contamination that has not been well investigated $(24,25)$. The cow dung samples in present investigation were found to harbor a huge array of microorganisms as assumed (Table 1). All the samples contained viable bacteria and fungi in a range of $1.5 \times 10^{7}$ to $5.8 \times 10^{8} \mathrm{cfu} / \mathrm{g}$ and $1.0 \times 10^{7}$ to $8.0 \times 10^{8} \mathrm{cfu} / \mathrm{g}$, respectively. Heterotrophic and pathogenic bacteria were also recovered in significant quantities from all the samples. Specific bacterial proliferation was confirmed through the biochemical tests. All the samples were found to carry Bacillus spp. and Staphylococcus spp. in average of $10^{5}$ and $10^{6} \mathrm{cfu} / \mathrm{g}$, respectively. Pseudomonas spp., Escherichia coli, Klebsiella spp. and fecal coliforms were also present in almost all samples in average of $10^{5}$ $\mathrm{cfu} / \mathrm{ml}$. Vibrio spp. were recovered in 5 samples, whereas Salmonella spp. were found in three samples in an average of $10^{4} \mathrm{cfu} / \mathrm{g}$ (Table 3.1). All the tested samples were free from the presence of Shigella spp.

Previous studies reported the presence of heterotrophic bacterial genera such as Acinetobacter spp., Bacillus spp., Flavobacterium spp., Klebsiella spp., Micrococcus spp., Pseudomonas spp. and Serratia spp. from animal manures $(22,23,26)$. Girija et al. (27) in 2013 also detected a huge array of microorganisms in cow dung samples by

TABLE 1. Isolation and quantification of microbial inhabitants of the cow dung samples

\begin{tabular}{|c|c|c|c|c|c|c|c|c|c|c|}
\hline Sample & $\begin{array}{l}\text { TVB } \\
\text { (cfu/g) }\end{array}$ & $\begin{array}{l}\text { Fungi } \\
\text { (cfu/g) }\end{array}$ & $\begin{array}{l}\text { E. coli } \\
\text { (cfu/g) }\end{array}$ & $\begin{array}{l}\text { Klebsiella } \\
\text { spp. (cfu/g) }\end{array}$ & $\begin{array}{c}\text { Fecal } \\
\text { coliform } \\
\text { (cfu/g) }\end{array}$ & $\begin{array}{l}\text { *Salmonella } \\
\text { spp. (cfu/g) }\end{array}$ & $\begin{array}{c}\text { Pseudomonas } \\
\text { spp. (cfu/g) }\end{array}$ & $\begin{array}{l}\text { Bacillus } \\
\text { spp. (cfu/g) }\end{array}$ & $\begin{array}{c}\text { *Vibrio } \\
\text { spp. (cfu/g) }\end{array}$ & $\begin{array}{l}\text { Staphylococcus } \\
\text { spp. (cfu/g) }\end{array}$ \\
\hline CDS-1 & $5.0 \times 10^{8}$ & $1.0 \times 10^{7}$ & $3.0 \times 10^{5}$ & $7.5 \times 10^{5}$ & $4.7 \times 10^{5}$ & 0 & $4.0 \times 10^{5}$ & $3.0 \times 10^{6}$ & 0 & $7.0 \times 10^{6}$ \\
\hline CDS-3 & $1.5 \times 10^{7}$ & $1.8 \times 10^{7}$ & $5.0 \times 10^{4}$ & $2.0 \times 10^{4}$ & $3.0 \times 10^{4}$ & 0 & $3.0 \times 10^{5}$ & $1.2 \times 10^{6}$ & $6.0 \times 10^{4}$ & $1.5 \times 10^{6}$ \\
\hline CDS-4 & $3.4 \times 10^{8}$ & $8.0 \times 10^{8}$ & $1.2 \times 10^{5}$ & $1.0 \times 10^{4}$ & $9.0 \times 10^{4}$ & $3.0 \times 10^{4}$ & $1.0 \times 10^{6}$ & $4.5 \times 10^{5}$ & $1.0 \times 10^{4}$ & $5.5 \times 10^{7}$ \\
\hline CDS-6 & $5.8 \times 10^{8}$ & $1.0 \times 10^{8}$ & $2.7 \times 10^{5}$ & $3.0 \times 10^{5}$ & $4.0 \times 10^{4}$ & 0 & $1.2 \times 10^{6}$ & $1.5 \times 10^{5}$ & $2.0 \times 10^{4}$ & $9.5 \times 10^{7}$ \\
\hline CDS-7 & $4.3 \times 10^{8}$ & $1.0 \times 10^{7}$ & $5.1 \times 10^{5}$ & 0 & $8.0 \times 10^{4}$ & $1.6 \times 10^{5}$ & $2.5 \times 10^{5}$ & $2.5 \times 10^{5}$ & $4.1 \times 10^{5}$ & $7.0 \times 10^{6}$ \\
\hline CDS-8 & $3.2 \times 10^{8}$ & $1.2 \times 10^{7}$ & 0 & 0 & 0 & 0 & $1.0 \times 10^{5}$ & $3.5 \times 10^{5}$ & 0 & $4.3 \times 10^{5}$ \\
\hline
\end{tabular}

TVB $=$ Total viable bacteria CDS $=$ Cow dung sample

The experiments were in triplicates. Average count (cfu/g) have been shown here.

*Bacterial load after enrichment (Prior to enrichment, the recovery was nil).

Shigella spp. was absent in all samples. 
TABLE 2. Antimicrobial activity of the cow dung samples

\begin{tabular}{ccccccc}
\hline & \multicolumn{5}{c}{ Zone of inhibition (mm) against test bacteria } \\
\cline { 2 - 6 } Sample & E. coli & $\begin{array}{c}\text { Klebsiella } \\
\text { spp. }\end{array}$ & $\begin{array}{c}\text { Salmonella } \\
\text { spp. }\end{array}$ & Vibrio spp. & $\begin{array}{c}\text { Pseudomonas } \\
\text { spp. }\end{array}$ & Bacillus spp. \\
\hline CDS-1 & $15 \mathrm{~mm}$ & $17 \mathrm{~mm}$ & $16 \mathrm{~mm}$ & $20 \mathrm{~mm}$ & $18 \mathrm{~mm}$ & $20 \mathrm{~mm}$ \\
CDS-2 & $12 \mathrm{~mm}$ & $19 \mathrm{~mm}$ & $19 \mathrm{~mm}$ & $14 \mathrm{~mm}$ & $11 \mathrm{~mm}$ & $18 \mathrm{~mm}$ \\
CDS-3 & $13 \mathrm{~mm}$ & $14 \mathrm{~mm}$ & $11 \mathrm{~mm}$ & $12 \mathrm{~mm}$ & $20 \mathrm{~mm}$ & $14 \mathrm{~mm}$ \\
CDS-4 & 0 & 0 & $15 \mathrm{~mm}$ & $14 \mathrm{~mm}$ & 0 & $11 \mathrm{~mm}$ \\
CDS-5 & $10 \mathrm{~mm}$ & $12 \mathrm{~mm}$ & $12 \mathrm{~mm}$ & $13 \mathrm{~mm}$ & $10 \mathrm{~mm}$ & $14 \mathrm{~mm}$ \\
CDS-6 & 0 & $10 \mathrm{~mm}$ & 0 & 0 & $12 \mathrm{~mm}$ & $11 \mathrm{~mm}$ \\
CDS-7 & $14 \mathrm{~mm}$ & $18 \mathrm{~mm}$ & $19 \mathrm{~mm}$ & $17 \mathrm{~mm}$ & 0 & $13 \mathrm{~mm}$ \\
CDS-8 & $13 \mathrm{~mm}$ & $13 \mathrm{~mm}$ & $15 \mathrm{~mm}$ & $11 \mathrm{~mm}$ & $13 \mathrm{~mm}$ & $12 \mathrm{~mm}$ \\
\hline
\end{tabular}

$\mathrm{CDS}=$ Cow dung samples

metagenomics approaches

In vitro Antibacterial activity of the fresh cow dung samples. Cow dung can be explored as a source of potential antimicrobial metabolites due to its diverse microflora (28). Cow dung has been used in ayurvedic treatments, used for biogas production and increasing crop productivity from ancient times. Evidence suggests that cow dung possesses antiseptic and prophylactic or disease preventive properties. A number of studies reported the highly effective antibacterial features of cow dung extract against different pathogenic agents (9, 29-31). Some studies also revealed nematicidal activity and probiotic activities of cow dung along with antibacterial activity $(9,32,33)$.

In the present study, all the cow dung samples exhibited significant antibacterial activities against all the bacteria tested (Table 2). Samples CDS- 1, 2, 3, 5 and 8 were found to effectively inhibit the growth of all the bacteria tested such as E. coli, Klebsiella spp., Salmonella spp., Vibrio spp., Pseudomonas spp. and Bacillus spp. All the samples showed antibacterial activity against Bacillus spp. With few exceptions, all the other bacteria tested were affected by most of the samples (Table 2).

\section{CONCLUSIONS}

The findings of the present study revealed that all the cow dung samples contained huge array of microorganisms inclusive of pathogenic bacteria. The samples exhibited potential antimicrobial activity against different bacteria as well. Presence of pathogens claimed the need for safe application of cow dung in the agricultural land. However, the presence of diversified microorganisms and antibacterial potential in the cow dung samples seeks further comprehensive screening and investigation for the presence antibacterial, antifungal and antiviral metabolites. The application of cow dung microflora with considerable antimicrobial potential can result in the promotion of human health. Investigation can also be made for their agricultural, medicinal and nutritional significance.

\section{ACKNOWLEDGEMENT}

We thank Microbiology Laboratory, Stamford University Bangladesh for providing us with the facilities to carry out the experiments.

\section{REFERENCES}

1. Gupta KK, Aneja KK, Rana D. 2016. Current status of cow dung as a bioresource for sustainable development. Bioproc. Bioeng. 3: 28.

2. Garg AK, Mudgal V. 2007. Organic and mineral composition of Gomeya (cow dung) from Desi and crossbred cows - a comparative study. Int. J. Cow Sci. 3:1-2.

3. Randhawa GK, Kullar JS. 2011. Bioremediation of pharmaceuticals, pesticides, and petrochemicals with gomeya/cow dung. ISRN Pharmacol. 2011: 362459 .

4. Nene YL. 1999. Utilizing traditional knowledge in agriculture. Traditional knowledge system of India and Sri Lanka.

5. Manyi-Loh CE, Mamphweli SN, Meyer EL, Makaka G, Simon M, Okoh AI. 2016. An overview of the control of bacterial pathogens in cattle manure. Int. J. Environ. Res. Public Health. 13 (9): 843.

6. Johannessen GS, Frøseth RB, Solemdal L, Jarp J, Wasteson Y, Rørvik LM. 2004. Influence of bovine manure as fertilizer on the bacteriological quality of organic Iceberg lettuce. J. Appl. Microbiol. 96: 787-794.

7. Dhama K, Chauhan RS, Singhal L. 2005. Anti-cancer activity of cow urine: current status and future directions. Int. J. Cow Sci. 1:1-25.

8. Nene YL. 2003. Crop diseases management practices in ancient, medieval, and premodern India. Asian Agri. Hist. 7 (3): 185-201.

9. Sharma B, Sing M. 2015. Isolation and characterization of bacteria from cow dung of desi cow breed on different morpho-biochemical parameters in Dehradun, Utrakhand, India. Int. J. Adv. Pharm. Biol. Chem. 4 (2): 1-6.

10. Das NC, Hossaini F, Munshi SK. 2017. Influence of tannery wastes and the surrounding environment of tannery industries on microbial growth and proliferation. Stam. J. Microbiol. 7 (1): 14-18.

11. Cappuccino JG, Sherman N. 1996. Microbiology - A laboratory manual. The Benjamin/Cummings Publishing Co., Inc., Menlo Park, California.

12. Chowdhury FFK, Acharjee M. Noor R. 2016. Maintenance of environmental sustainability through microbiological study of pharmaceutical solid wastes. Clean Soil Air Water. 44 (3): 309-316. 
13. Acharjee M, Jahan F, Rahman F, Noor R. 2013. Bacterial proliferation in municipal water supplied in mirpur locality of Dhaka city, Bangladesh. Clean - Soil. Air.Water. 41 (9999): 1-8.

14. Ahmed T, Urmi NJ, Munna MS, Das KK, Acharjee M, Rahman MM, et al. 2014. Assessment of microbiological proliferation and in vitro demonstration of the antimicrobial activity of the commonly available salad vegetables within Dhaka metropolis, Bangladesh. Am. J. Agri. Forestr. 2 (3): 55-60.

15. Acharjee M, Ahmed E, Munshi SK, Noor R. 2014. Validation of $\boldsymbol{\gamma}$ irradiation in controlling microorganisms in fish. Nutri. Food. Sci. 44 (3): 258-266.

16. Rahman F. Noor R. 2012. Prevalence of pathogenic bacteria in common salad vegetables of Dhaka Metropolis. Bangladesh. J. Botany. 41 (2): 159162.

17. Colwell RR. 2000. Non-culturable microorganisms in the environment. American Society of Microbiology, Washington DC, USA.

18. Oliver JD. 2005. The viable but nonculturable state in bacteria. J. Microbiol. 43: 93-100.

19. Alfrad EB. 2007. Bensons Microbiological Applications. Mcgraw-Hill Book Company, New York.

20. Jagessar RC, Mars A, Gones G. 2008. Selective antimicrobial properties of leaf extract against various micro-organisms using disc diffusion and agar well diffusion method. J. Nat. Sci. 6 (2): 24-38, 2008

21. Hussain A, Wahab S, Zarin I, Hussain MDS 2010. Antibacterial activity of the leaves of Coccinia indica (W. and A) W of India. Adv. Biol. Res. 4 (5): 241-248

22. Gupta KK, Rana D. 2016. Isolation and evaluation of cow dung bacteria for their antimicrobial potential. Biotech. Int. 9 (2): 47-54

23. Rupela OP, Gopalakrishnan S, Krajewski M, Sriveni M. 2003. A novel method for the identification and enumeration of microorganisms with potential for suppressing fungal plant pathogens. Biol. Fertil. Soils. 39: $131-134$.
24. Hozzein WN, Ali DMI, Ali MIA. 2007. Genus diversity and antibacterial activities of some desert actinomycetes. J. Union Arab. Biologists. 17B: 1530 .

25. Hozzein WN, Rabie W, Ali MIA. 2011. Screening the Egyptian desert actinomycetes as candidates for new antimicrobial compounds and identification of a new desert Streptomyces strain. African J. Biotechnol. 10: 2295-2301.

26. Akinde SB, Obire O. 2008. Aerobic heterotrophic bacteria and petroleumuti- lizing bacteria from cow dung and poultry manure. World J. Microbiol. Biotechnol. 24: 1999-2002.

27. Girija D, Deepa K, Xavier F, Antony I, Shidhi PR. 2013. Analysis of cow dung microbiota - a metagenomic approach. Indian J. Biotech. 12: 372-378.

28. Sawant AA, Hegde NV, Straley BA, Donaldson SC, Love BC, Knabel SJ, et al. 2007. Antimicrobial-resistant enteric bacteria from dairy cattle. Appl. Environ. Microbiol. 73: 156-163.

29. Shrivastava S, Mishra A, Pal A. 2014. Cow dung - a boon for antimicrobial activity. Lifesci. Leaflets. 55: 60-63.

30. Abdel-Mohsein H, Yamamoto N, Otawa K, Tada C, Nakai Y. 2010. Isolation of bacteriocin like substances producing bacteria from finished cattle-manure compost and activity evaluation against some food-borne pathogenic and spoilage bacteria. J. Gen. Appl. Microbiol. 56 (2): 151-61.

31. Sathasivam,AK, Muthuselvam M. 2010. Antimicrobial activities of cow urine distillate against some clinical pathogens. Global J. Pharmacol. 4 (1): 41-44.

32. Hao L, Wang X, Zhang K, Xu Y, Zhou L, Li G. 2014. Identification and nematicidal activity of bacteria isolated from cow dung. Ann Microbiol. 64 407-411.

33. Klaenhammer TR. 2000. Probiotic bacteria: Today and tomorrow. J. Nutr. 130: 415-416 